\title{
Enabling service innovation: A dynamic capabilities approach
}

\author{
Daniel Kindström, Christian Kowalkowski and Erik Sandberg
}

\section{Linköping University Post Print}

\section{Tweet}

N.B.: When citing this work, cite the original article.

Original Publication:

Daniel Kindström, Christian Kowalkowski and Erik Sandberg, Enabling service innovation: A dynamic capabilities approach, 2013, Journal of Business Research, (66), 8, 1063-1073. http://dx.doi.org/10.1016/j.jbusres.2012.03.003

Copyright: Elsevier http://www.elsevier.com/

Postprint available at: Linköping University Electronic Press

http://urn.kb.se/resolve?urn=urn:nbn:se:liu:diva-77122 


\title{
Enabling service innovation - A dynamic capabilities approach
}

\author{
Daniel Kindström, Linköping University \\ Christian Kowalkowski, Hanken School of Economics \\ Erik Sandberg, Linköping University
}

JANUARY, 2012

The authors are indebted to Heiko Gebauer for insightful comments on earlier versions of this paper and to Keith Crosier for his patient and invaluable editing services. They also gratefully acknowledge the financial support of the Jan Wallander and Tom Hedelius Foundation and Vinnova (The Swedish Governmental Agency for Innovation Systems).

Send correspondence to Daniel Kindström, Linköping University, Department of Management and Engineering, SE-581 83 Linköping, Sweden; telephone +46-13281571 (daniel.kindstrom@liu.se); Christian Kowalkowski, Hanken School of Economics, CERS - Center for Relationship Marketing and Service Management, PO Box 479, FIN-00101 Helsinki, Finland (christian.kowalkowski@hanken.fi); Erik Sandberg, Linköping University, Department of Management and Engineering, SE58183 Linköping, Sweden (erik.sandberg@liu.se). 


\title{
Enabling service innovation - A dynamic capabilities approach
}

\begin{abstract}
The point of departure for this article is the need for product-centric firms to compete in the market by adding services to their portfolio, which requires a greater focus on service innovation if they are to remain competitive. A major challenge associated with the shift from product-centeredness to a product-and-service orientation is the management of the essential dynamic capabilities of sensing, seizing, and reconfiguring needed for service innovation. The research study reported identifies key microfoundations forming the basis of successful realignment of a firm’s dynamic capabilities so as to achieve a better fit with service innovation activities. Eight qualitative case studies of product-centric firms form the basis of the study.
\end{abstract}

The findings make three primary contributions to the body of knowledge. First, they extend the existing literature on dynamic capabilities by specifically discussing microfoundations related to service innovation. Second, the study extends existing work on service innovation into the manufacturing industries by identifying the key microfoundations in that context. Third, the research provides empirical evidence of dynamic capabilities in practice, especially in product-centric settings in which the service context is novel.

Keywords: Service innovation, dynamic capabilities, microfoundations, services, service orientation, strategy. 


\section{Introduction}

Though product-centric firms may today acknowledge the transition toward services, many struggle to envision how they would best manage the process in practice. That uncertainty is understandable, given that an increased service orientation often involves a major shift to a new strategic direction, a new organizational structure, and new skills (Gebauer, Gustafsson, and Witell, 2011; Jacob and Ulaga, 2008; Kowalkowski, Kindström, Brashear, Brege and Biggeman, 2012; Raddats and Easingwood, 2010). To be able to develop new services continuously and comprehend the underlying business logic of service provision, firms must develop dynamic capabilities (Teece, Pisano and Shuen, 1997) that can enable service innovation (Den Hertog, van der Aa and de Jong, 2010; Fischer, Gebauer, Gregory, Ren and Fleisch, 2010; Martin and Horne, 1992). Service innovation and its associated dynamic capabilities are a key concern for many firms today, some researchers citing them as key drivers of consistent high performance over time (Gallouj and Weinstein, 1997; Sundbo, 1997). An understanding of these capabilities is an important first step in being able to reap the benefits of future service innovation; without it, a firm risks becoming trapped in activities delivering everdecreasing returns (Tallman, 2003; Teece, 2007; Winter, 2003) and erecting increasingly rigid barriers (Leonard-Barton, 1992).

The emerging field of dynamic capabilities provides a relatively new perspective from which to approach service innovation and strategic renewal. . The focus on change inherent in the concept is a difference in comparison to previous literature and a reason for why dynamic capabilities contributes to our understanding of service innovation in this research. Based on the idea that unique bundles of resources form the basis for competitive advantage, the dynamic capabilities 
perspective views sustainable competitive advantage as the ability to create, extend, and modify valuable resources and capabilities over time (Helfat, Finkelstein, Mitchell, Peteraf, Singh, Teece and Winter, 2007). For analytical purposes, dynamic capabilities can be disaggregated into three distinct activities: sensing opportunities and threats, seizing those opportunities, and maintaining competitiveness by reconfiguring resources (Teece, 2007). Underpinning these three generic, corporatelevel capabilities are 'microfoundations', defined by Teece (2007, p. 1319) as “distinct skills, processes, procedures, organizational structures, decision rules, and disciplines”, form the organizational basis of dynamic capabilities. Those are consequently at the very core of understanding the creation of competitive advantage. The purpose of the research study reported here is to identify the key microfoundations that permit product-centric firms to build the dynamic capabilities that can facilitate service innovation. Focusing on microfoundations enables researchers to drill down to a level of detail that would not otherwise be possible and thereby build a firm conceptual foundation for service innovation, and to devise strategies for its implementation by management.

Although the concept of dynamic capabilities is relatively generic, most research has tended to focus on its product-related and technology-related aspects. Yet product-centric firms, which have traditionally based their competitiveness on product leadership and protection by patents, are increasingly shifting their focus toward services and innovation in service delivery. Consequently, it is timely to apply the concept of dynamic capabilities and their microfoundations directly to the pressing challenge of infusing a greater element of service, as a means to effective innovation.

The study reported here therefore aims to contribute to theory by adding a discussion of dynamic capabilities to the service-oriented literature and introducing 
the service dimension into the strategic analysis. The point of departure is a broad view of service innovation, such as that taken by Bessant and Davies (2007), dealing not only with the uniqueness or newness of the service, but also of innovations in other areas of the service system (Drejer, 2004; Gallouj, 2002; Gallouj and Weinstein, 1997), such as the delivery processes, customer interfaces, and the buyer-seller relationship (de Jong and Vermeulen, 2003). Service innovation can also be focused on customer roles and competences in the service process (Gallouj and Weinstein, 1997; Michel, Brown and Gallan, 2008).

This remainder of this article begins with a brief overview of the concept of service innovation, followed by a discussion of the dynamic capability framework and its links with services and service innovation. Next, the case-study methodology is described and discussed, before the findings are presented for the separate activities of 'sensing', 'seizing' and 'reconfiguring'. The article concludes with a discussion of the implications of the study for academics and practitioners.

\section{The nature of service innovation}

Service innovation is a broad concept that encompasses a considerable number of distinct dimensions, discussed in the literature by Bessant and Davies (2007), de Jong and Vermeulen (2003), Edvardsson and Olsson (1996), and Tidd, Bessant, and Pavitt (2001). Specific examples of innovation include service development processes (Kindström and Kowalkowski, 2009; Song, Song and Di Benedetto, 2009), capability development (Den Hertog et al., 2010; Fischer et al., 2010), learning (Stevens and Dimitriadis, 2004), organizational adaptation (Neu and Brown, 2008), and culture (Gebauer and Friedl, 2005). Firms aiming to master the intricacies of service innovation and take full advantage of the potential benefits of service innovation must address that wide array of component parts. Yet many of the service innovation 
frameworks applied in practice focus solely on changes in the firm's view of service or on the processes of service provision. The study reported here proceeds from the proposition that service innovation is a multi-dimensional, organization-wide challenge to the managers charged with its design and implementation, and that a comprehensive conception of it is therefore essential.

Although service innovation has a catalytic role in shaping new markets and creating new business opportunities, most product-centric firms still adhere to the ‘invention’ model, which prioritizes the conventional, structured processes and platforms for product development that are typical of mature, product-centered firms (Ostrom et al., 2010). Innovation is often taken to be synonymous with new technology in the context of new product development and manufacturing processes (Utterback, 1994). There are few insights into the means by which product-centric firms might achieve successful service innovation, and thereby differentiate themselves by 'infusing' services and solutions (Ostrom, Bitner, Brown, Burkhard, Goul, Smith-Daniels, Demirkan and Rabinovich, 2010).

\section{The nature of dynamic capabilities}

The so-called resource-based view of strategy has been criticized for not considering how to develop and maintain a firm's resources over time (Teece et al., 1997). The concept of dynamic capabilities, which takes the resource-based view as

one of its starting points, aims to address that problem. A widely adopted definition of dynamic capabilities is that they are routines within the firm's managerial and organizational processes that aim to gain, release, integrate and reconfigure resources (Teece et al., 1997) and are therefore change-oriented (Winter, 2003; Zollo and Winter, 2002). They not only seek to adapt a firm’s resource base to evolving customer demands and market trends, such as an increased demand for services, but 
also allow firms to shape their environment through innovation and collaboration with their customers and other key actors (Teece, 2007).

Given the focus on change, the original conception of dynamic capabilities was in the context of rapidly changing environments (Teece et al., 1997). The recognized need for firms in relatively stable environments to gain, release, integrate and reconfigure their resources in response to the threats and opportunities of change in the marketplace has led to a change in the traditional perspective (Eisenhardt and Martin, 2000). Given that product-centric firms are confronted by changing markets, new customer demands, new (often low-cost) competition, and commoditization of products, the adoption of a dynamic capability framework is both appropriate and timely. Some observers (Prasnikar, Lisjak, Buhovac and Stembergar, 2008; Day, 2004) feel that managers need to understand both their firms' core technological capabilities and its marketing capabilities, to be able to decide which capabilities should be developed and which discontinued as irrelevant. As the business focus of product-centric firms shifts to services, the need increases to identify the necessary capabilities and propose means for their implementation.

The tendency to discuss capabilities in a product- and technology-development context (e.g., Eisenhardt and Martin, 2000; Lisboa et al., 2011; Teece, 2007) often leads to the neglect of the service component.. The increasing importance of service innovation for many firms and the fact that changes in the external environment can decrease the value of current dynamic capabilities, together generate the imperative to extend discussions about the dynamic capabilities framework (Den Hertog et al., 2010; Fischer et al., 2010). The introduction of service innovation into the scenario does not necessarily demand modification of the overarching generic framework. Instead, firms must extend the underlying structure - that is, the microfoundations 
(Teece, 2007) - by taking the service aspect into account. A focus on those microfoundations rather than overarching capabilities, favours deeper insights and an analysis better attuned to initiatives and procedures that directly influence service innovation.

There is a need to distinguish a number of distinct microfoundations geared to the facilitation of service innovation. Identification and implementation of such subcategories will extend the dynamic capabilities framework, rendering it more comprehensive, well attuned to the contemporary characteristics of the industry and its context, and better able to address the particular challenges of service innovation.

For analysis of the empirical data, the study reported here adopted the threefold classification of firm-level dynamic capabilities proposed by Teece (2007): sensing, seizing, and reconfiguring. The aim was to develop a more inclusive structural framework, which would include the microfoundations at the heart of the concept of dynamic capabilities. These three constructs are not novel. Indeed, their conceptually relationship to the exploration-exploitation dichotomy (Lisboa et al., 2011) and equivalent constructs in the literature of market orientation (Kohli and Jaworski, 1990) attests to the relevance and applicability of the constructs. Nevertheless, the addition of a dynamic capabilities perspective and associated microfoundations permits a more direct connection to underlying factors.

\subsection{Sensing capabilities}

'Sensing' refers essentially to the gathering of relevant marketing intelligence. It is crucial for businesses in pursuit of competitive advantage to be able to scan global and local markets, assess customers’ actual preferences, and capture ideas internally from a wide range of employees (Day, 2004; Teece, 2007). In the context of market orientation, Kohli and Jaworski (1990) describe a comparable process of intelligence 
generation followed by the dissemination of information. Voola and O'Cass (2010) focus on aspects relating to the sensing capability in their discussion of 'proactive' market orientation.

Gathering information about customers is a particularly important basis for the development and provision of services (Edvardsson, Gustafsson, Kristensson, Magnusson and Matthing, 2006; Gallouj and Weinstein, 1997). Developing and delivering a service typically involves several stages, characterized by customer involvement and continuous feedback loops of interaction and mutual adjustment (Kindström and Kowalkowski, 2009; Stevens and Dimitriadis, 2004). The sensing of service-related opportunities is inherently complex, because those are apt to reside deep in customer-specific processes and activities and are typically understandable only after the co-creation of the service in the customers' unique contexts (Vargo and Lusch, 2008).

\subsection{Seizing capabilities}

To 'seize' capabilities, it is not sufficient to invest in technology and complementary assets. A business model must also exist that is capable of sustaining and exploiting new opportunities as they present themselves (Chesbrough, 2010; Teece, 2010). Similarly, Kohli and Jaworski (1990) and Atuahene-Gima (1996) call for 'responsiveness', by which they mean the readiness to disseminate market intelligence throughout the firm and duly take initiatives based upon it. The productcentric business model is inappropriate, in the sense that it may cause the loss of many previously sensed service opportunities in transit between management levels or functions, or between resources for sensing and seizing. Firm decision-making processes geared towards products can miss service innovation opportunities that would be seized by a more service-oriented capability. 
Proficiency in service design and delivery is as dependent upon organizational innovations as upon the development and implementation of particular service innovations. The reason is at least partly that many of the challenges entailed in changing from a product-orientation to a service-orientation and becoming more customer-centric require are internal to the firm (Shah et al., 2006).

\subsection{Reconfiguring Capabilities}

It is widely recognized that successful firms often become complacent and rigid over time (Leonard-Barton, 1992), frequently fine-tuning their current business model by focusing on exploitation rather than exploration. A slight adjustment of the model may be enough to sustain exploitation of the current set of opportunities but, when the environment changes, management will need to undertake more substantial reconfiguration (Helfat et al., 2007).

Although a firm’s business model and associated business logic may be sound enough to benefit from current product-based opportunities, they may not be sufficient to take advantage of emerging opportunities for service innovation, even if those are sensed. To do so, the firm must reconfigure fundamental elements of its business model and its current resources (Kindström, 2010) and break embedded path dependencies that are faulty.

\section{Methodology}

The aim of this study was to explore key microfoundations for service innovation in product-centric firms, a complex and context-bound process. Accordingly, the multiple case method was chosen as the most appropriate vehicle for gathering the necessary data, since it allows analysis of issues from different standpoints and is considered to be an effective means of gaining new knowledge about a specific 
phenomenon (Eisenhardt \& Graebner, 2007). Specifically, multiple case analysis was expected to facilitate in-depth understanding of the contextual factors and underlying processes influencing dynamic capabilities and service innovation in product-centric firms, and thereby develop a refined and extended conceptualization of the servicebased microfoundations of dynamic capabilities. The focus is on product-centric firms because, to the best of our knowledge, no studies have yet explored the microfoundations of service innovation, which is a pressing issue in industry today.

\subsection{Sample}

Three criteria were applied to the selection of appropriate cases from a pool of firms taking part in two ongoing research projects on service transition in manufacturing industry. First, a candidate firm had to have existing professional experience of service innovation within its own organization and must have expanded its offering beyond its core product. Second, for reasons of practicality, access to key informants had to be readily available. Third, the case firms should yield qualitative richness and diversity of data, rather than delivering statistical representativeness, each one standing on its own merits as a unit of analysis (Eisenhardt and Graebner, 2007; Yin, 2003). In short, sample selection was based theoretical sampling, not statistical sampling, in pursuit of superior generalizability of the findings (Gibbert, Ruigrok, and Wicki, 2008).

The selection process took care to distinguish basic, product-oriented services such as repair, maintenance or spare parts supply - from more advanced, processoriented services -such as long-term service and rental agreements, process optimization or fleet management (cf. Mathieu, 2001). While the eight firms eventually selected for the study had all provided basic services for a long time, the mode of provision generally lacked structure and strategic direction with respect to 
development and innovation. Though the firms studied thus did deliver basic services, to varying degrees, only a few offered a wide range of advanced services or derived a large share of their revenue from such services.

Application of the selection criteria resulted in the sample of eight (anonymized)

firms described in Table 1. All are long-established, founded more than 60 years ago, and successful in their fields. As the table shows, they collectively represent a good range of industry types and product-service offerings.

Table 1 here

\subsection{Data collection}

Data for analysis were collected by means of: face-to-face interviews, focus group discussions, and extraction from internal and external secondary sources. The rationale for the focus group method, in particular, was to strengthen the findings of the study in terms of their contribution to both academic and practitioner understanding.

Interview respondents, drawn from the eight case-study firms, represented three distinct organizational groupings: general business managers, service managers, and service engineers. The rationale for this sample profile was to minimize the scope for bias inherent in relying on answers filtered through the personal interpretation of questions by a relatively small number of respondents. Interviews were semistructured, guided by a case study protocol (Gibbert et al., 2008; Yin, 2003) based on inputs from the service innovation literature and the dynamic capability framework.

The approach of the focus group element of the research design had much in common with what Van de Ven and Johnson (2006) call "engaged scholarship research ... a collaborative form of inquiry in which academics and practitioners 
leverage their different perspectives and competencies to coproduce knowledge about a complex problem or phenomenon” (p. 803). Participants in one group which met several times were drawn from all eight participating firms. Discussion focused on the continuing preliminary conclusions of the study, as an input to refinement of the analysis and eventual validation of the results (Matthyssens and Vandenbempt, 1998; Stewart and Shamdasani, 1990). Given that the researchers and their practitioner partners had established mutual trust during the research projects, and that none of the participating firms was in competition with another, the atmosphere during the discussions was open and honest.

\subsection{Data analysis}

The participating researchers audio-recorded the majority of the interviews, for subsequent transcription. Respondents reviewed the resulting write-ups, as a precaution against misunderstandings and errors of transcription (Gibbert et al., 2008). Analysis of the inputs from the depth interviews, focus-group discussions and secondary sources identified a number of service innovation skills, processes and procedures (that is, preliminary versions of microfoundations) across the sample. Theoretical triangulation of the written-up inputs optimized their internal validity and reliability (Yin, 2003), thereby substantiating the conclusions drawn (Gibbert et al., 2008). The results of that process were interpreted against the background of the literature relating to dynamic capabilities, service innovation, and the process of transition from product-centrism to the infusion of service into the offering. A sequence of iterations, switching sequentially between empirical results and theoretical inputs, generated and developed the new conceptual framework. This process has been termed “abductive” (Dubois and Gadde, 2002). The analyzed and processed data were lastly grouped and regrouped, systematically, into discrete related 
themes.

Following the methodological lead of Eisenhardt (1989) and Yin (2003), the process of analysis and interpretation carried out within-case analyses as a prelude to cross-case comparisons and pattern-matching procedures. This structured approach served to extract distinct microfoundations for service innovation from the preliminary versions identified by within-case analysis (see Table 5 for a brief summary of the prevalence of each microfoundation in the individual cases). The process furthermore increases the validity and robustness of the results and, among other things, permits comparison of findings among several firms.

A minimum of two participating researchers conducted the initial analysis of the collected data, before making a comparison and synthesis of their process notes at a later stage (Yin, 2003). The analysis achieved 'theoretical saturation’ before complete analysis of all eight cases. Since all case firms fulfilled the selection criteria, however, they were duly included in the general analysis. Furthermore, though a larger sample of firms would have enlarged the database, eight cases constitutes a manageable number (Eisenhardt, 1989).

Making the research method replicable by incorporating a semi-structured interview guide increased the reliability of the findings and conclusions, as did collating all of the collected transcripts. These procedures permit repetition of the study with similar outcomes (Yin, 2003).

\section{Findings: dynamic capabilities, microfoundations and service innovation}

Innovative service delivery is an inherently dynamic process, which is more dependent for its success than traditional product-centric marketing on continuous adaptation to the evolving nature of customer needs and the technological aspects of 
provision. The results of the study reported here demonstrate the need for an extended, sometimes completely new, armory of underlying initiatives and processes, if a firm offering its customers product-service solutions is to remain competitive. This finding goes beyond the concepts and microfoundations that have previously underpinned firms' traditional product operations, to the innovative behaviour that is necessary for the development of those dynamic capabilities that facilitate and support innovation in the provision of services. The case studies demonstrate the difficulties inherent in successfully competing in the current business arena if a firm’s dynamic capabilities rest solely on product-based microfoundations. In short, strategists seeking to identify and exploit the benefits to be derived from service innovation cannot rely on capabilities geared only to product-driven and manufacturing-driven innovation. This real-life challenge for service businesses provides a starting point for the discussion that follows.

Tables 2 to 4 list and define the identified microfoundations of service innovation, separately for the ‘sensing', ‘seizing' and 'reconfiguring' subsets described in Section 3. Descriptions of the microfoundations are accompanied by the critical managerial questions associated with them. The key aspects and success factors found in the participating firms help identify and develop these microfoundations.

\subsection{Sensing: new approaches to opportunity discovery}

The study found that firms seeking to increase the service content of their business portfolios and looking to service innovation to generate opportunities for value creation should employ new sensing activities in four main areas: customer-linked service sensing, service system sensing, internal sensing, and technology exploration. Table 2 summarizes the specific associated microfoundations, and the strategic questions they suggest. 
Table 2 here

\subsubsection{Customer-linked service sensing}

The fact that the value of new services and their underlying customer needs can differ from those of traditional products (Ulaga and Eggert, 2006) points to the possible need for firms to develop new competences and resources if they are to detect them. Given that service-oriented values tend to be intrinsic and intangible, they are more difficult to measure, as Grönroos (2007) has observed. Furthermore, service innovation arises more often than product innovation does from the sensing of local customer needs and problems (Edvardsson et al., 2006; Kowalkowski et al., 2012). Thus, in order to sense service opportunities, a firm needs to develop new resources, roles, and processes. For instance, when OutdoorCo were designing their first service performance contract, they discovered that their customers did not necessarily perceive the actual value of the service in the way they had been expected to. Instead of simply rolling out the planned service performance contract, the firm initiated a thorough pilot study, to discover what customers valued. The case study experience resulted in substantial changes to the design of the service as well as the delivery.

Firms typically use traditional marketing research techniques to learn about present customer needs, but the planning of service innovations may in practice demand involvement of customers in more proactive, collaborative roles (Edvardsson et al., 2006). Firms which take such initiatives will consult lead customers early in the service development process, and shape the expectations and design of new concepts jointly with their suppliers and customers. The enhanced linkages arising from such co-development activities have improved customer-sensing skills in practice. They also require, however, new intelligence-gathering processes that emphasize customer 
interaction, which will in turn demand that front-line staff acquire new competencies in the building of relationships and he stimulation of interaction. Despite the recognition of such new directions on the part of several case firms, none has yet developed its service sensing performance to any great extent.

\subsubsection{Service system sensing}

Customers are not the only source for the sensing of service innovation opportunities. Successful firms do access the wider service system for this purpose, but to a lesser extent than they do in pursuit of product innovation. Given that innovative service strategies are likely to involve other actors, such as local service delivery organizations, dealers and third-party service providers, firms tend to direct their sensing efforts at co-suppliers and other service system partners (De Vries, 2006; Kindström and Kowalkowski, 2009). The involvement of other parties is particularly evident in industries in which system integrators, consultants, and contractors are major influences on the specification of larger contracts. IndustrialPumpsCo, for example, has required an understanding of the activities and strategies of major consultancy firms and local contractors. The firm has seen the participation and commitment of these other actors as a prerequisite for success, whether they are developing new service initiatives or launching advanced versions of existing offerings. Similarly, AircraftCo has similarly been highly dependent on an understanding of key actors in the service system during the process of developing new services. For instance, the sensing of key service partners and subsystem providers was critical in the specification of its first aircraft availability contract.

\subsubsection{Internal service sensing}

Internal sensing for service innovation opportunities is particularly challenging for 
firms providing such services as technical consulting, maintenance, and free-ofcharge extended warranty as a means of supporting product sales. WeldingCo, for example, has found it difficult to capture new ideas and find support for an enhanced orientation toward service.

Many firms often do not manage their service provision in a structured and formal manner, with the result that the services concerned are not necessarily visible in financial statements and performance measurement systems (Gebauer and Friedl, 2005). Such ‘invisible’ services tend to attract limited management attention, even though they can have a substantial (albeit indirect) influence on turnover, profitability, and sales. At GasCo, one of the key drivers for an increased service orientation has been an understanding that service sales drive future product sales. An initial mapping of such semi-invisible services can have great potential in providing the initial impetus for service innovations and thereby instilling a sense of value and confidence in the service innovation process among key actors in the process. Firms have been found to derive such impetus for service-innovation projects from ideas and concepts that local enthusiasts based in subsidiaries have initiated (Kindström and Kowalkowski, 2009). The ability to identify and exploit such local initiatives is noticeable in firms with a more prevalent focus on service innovation.

\subsubsection{Technology exploration}

Service innovation often emphasizes the sensing of external technological opportunities (Lusch, Vargo and Tanniru, 2010). All of the case firms were well aware of the benefits potentially arising from the adoption of technologies, especially ICT (information and communication technology). OutdoorCo, for example, has cooperated with specialist external experts to develop RFID-based services. At MaterialsHandlingCo, service development had often been synonymous with ICT 
development in many ways. Instead of focusing on specific individual problems that could arise, the firm has continuously sensed technological frontiers and used that expertise to engage with external ICT specialists, in order to internalize future opportunities. For example, the internal technical platform has allowed the firm to connect its installed base of products to a wireless information system, enabling it to identify service innovation opportunities more effectively.

Technology sensing in the case firms differs from traditional product research in that there is no explicit link between probing technological possibilities and new product R\&D. Rather, technology sensing seeks to tap into technological development streams in order to shape the service innovation process.

\subsection{Seizing: capitalizing on service innovation opportunities}

The sensing of potential opportunities is only the first step toward capitalizing on service innovation opportunities. Realizing the potential of these opportunities by seizing and exploiting them is a vital prerequisite to the creation of value and the accruing of profits through service innovation. The core microfoundations identified with respect to seizing capability are service interactions, managing the service delivery process, structuring the service development process, and adopting new revenue mechanisms. Table 3 summarizes the specific associated microfoundations, and the strategic questions they suggest.

Table 3 here

\subsubsection{Service interactions}

Firms devising ad delivering services typically need to be conscious of their customers' entire business processes, including those of the customers' own customers (Anderson et al., 2007; Normann, 2001). Successful innovation in services 
implies increased interaction with customers and other actors in the service system (Alam, 2006; Sundbo, 1997). Firms should therefore also aim to achieve an overarching capability for interaction, as a means of increasing customer bonding. Such interactions were found to have given the case firms a chance to sense new opportunities for innovation and value creation, possibly including customer coinnovation (Mannervik and Ramírez, 2006). For example, GasCo’s service development process commonly involved both customers and internal sales staff, which created a sense of belonging in customers and a significantly reduced resistance to adoption of the firm's services.

Relationship building is critical for many firms, product-centered or servicecentered and regardless of the industry. The factor that distinguishes the interaction capability, in the study, is that the case firms have managed to seize opportunities for innovation and competitive advantage that have arisen over repeated cycles of interactive co-creation. Participants whose firms had exploited their interaction capability successfully often emphasized that value creation is a mutual process that ranges from actors in the service system to the customer. Interaction was not practiced for its own sake, but because it created arenas for the efficient exploitation of any associated opportunities that might arise. At GasCo, for instance, such arenas included repeated and choreographed customer visits. Firms well positioned in this regard are better able to seize innovation opportunities that arise, both on an ad hoc basis, which is common in many services (Gallouj and Weinstein, 1997; Kowalkowski et al., 2012), and to work efficiently in formal and informal interactions during the process. Such firms are also better at converting the learning from previous service activities into reusable components and thereby simplifying future exploitation initiatives (Davies et al., 2006). 


\subsubsection{Managing the service delivery process}

Most (though not yet all) firms see the management of a service delivery process and the associated configuration of resources as an important capability. Wellmanaged provision of a service also lays the groundwork for more efficient seizing of future opportunities, for instance by facilitating interaction. GasCo had developed a type of 'service script' that outlined the method for delivering certain services and interacting with customers, which requires service technicians to look for new service opportunities.

A service delivery process with high productivity requires the firm to use its service capacity effectively, which includes maintaining an optimal balance between service quality and cost efficiency (Grönroos and Ojasalo 2004). For IndustrialPumpsCo and WeldingCo, this process also involved a continuous balancing of the comparative strengths and weaknesses of their internal service functions and their external service partners. This balancing act includes a control-versus-flexibility trade-off (Kowalkowski et al., 2011), determining where in-house service units belong (typically at headquarters versus locally) and which services should be outsourced to external parties. Due to difficulties with knowledge transfer, technical integration, and control, the managers at IndustrialPumpsCo, for example, felt that

offering advanced process-orientated services in-house would be beneficial. They also determined, however, that relying on external service partners for more basic services would be a relatively simple option. At MaterialsHandlingCo, by contrast, the inhouse service operation, comprising more than 4,000 service technicians in Europe alone, had been a pivotal factor in its achievement of a strong position in the service market.

\subsubsection{Structuring the service development process}


In order to manage and develop the service business in a systematic manner and fully exploit service innovation opportunities, case firms expressed the need to have a structured service development process in place (Song et al, 2009). In many cases, the firms develop services only on an ad-hoc basis, which often results in unplanned and unprofitable customization. It is equally common for firms to have failed to develop services partly because development managers have tended to apply an unsuitable product development approach to the service development process and have underestimated service-specific challenges, despite the many differences between the two contexts. For example, whereas product development processes normally require heavy investment at the outset, with strong emphasis on R\&D and prototyping, successful projects tend to require the allocation of more resources during the setting up of a delivery organization and the launching of the service (Kindström and Kowalkowski, 2009; Lovelock, 1984). Aware of this tendency, VehicleCo developed a completely new service development process in parallel with the product development process. GasCo and MaterialHandlingCo had also addressed the need for separate processes and emphasized the later phases of service development, such as the actual selling of services, consequently partly integrating sales training into the development process.

\subsubsection{Adopting new revenue mechanisms}

Seizing on a service innovation completely requires a firm to be able to extract revenue from the innovation. Most of the case firms struggled with this aspect of the operation. To varying extents, they devised innovative mechanisms to increase their service revenue, based on fixed or dynamic pricing, profit sharing, and the availability agreements based on productivity. This finding is consistent with those of Lay, Schroeter, and Biege (2009), and Ng, Maull and Yip (2009). The basis for these 
mechanisms is often the value-in-use that the services create throughout the life cycle of the product rather than by product ownership. The actual value-in-use is determined in the context of a customer's own use, and is thus uniquely determined by the customer, who will be inherently idiosyncratic and process-oriented. Value-inuse is a higher-order concept than value-in-exchange, the negotiated evaluation that buyers and sellers offer and receive among themselves; it is therefore a limited part of value creation (Kowalkowski, 2011).

VehicleCo and MiningCo both developed profit-sharing schemes with a few large customers. Rather than charging for equipment and associated spare parts on a priceper-unit basis, both firms' based their earnings on the productivity that the service stimulates across the customer's entire operation. Similarly, AircraftCo had revised its traditional revenue model, which based receipts on the number of spare parts sold and the amount of time involved in maintenance, for one of its services. Revenues were instead predicated on the availability of its product to the customer.

\subsection{Reconfiguring: shifting the competitive arena}

A focus on sensing and seizing current service innovation opportunities is often sufficient to produce a short-term competitive advantage. More effort is needed, however, if that advantage is to be sustainable (Helfat et al., 2007; Zahra et al., 2006). In order to sustain service innovation initiatives over time and maintain appropriate value in the face of changing markets, technologies, and customer demands, firms must have in place processes and competencies that will allow them to transform and reconfigure their resource base (Normann, 2001). Such challenges require a reconfiguring capability that identifies microfoundations focused on the orchestration of the service system, balancing product- and service-innovation related assets and the development of a service-oriented mental model. Table 4 summarizes the specific 
associated microfoundations, and the strategic questions they suggest.

Table 4 here

\subsubsection{Orchestrating the service system}

When a firm increases its focus on service innovation, one of the most complex competences demanded is the ability to orchestrate the service system efficiently. In the case firms, service innovation (especially with regard to advanced services) frequently demanded the inclusion of external actors throughout the entire service system (Normann, 2001). AircraftCo, for example, had to manage the behavior of external service providers who exerted a direct influence on the performance of the firm's services and on their perceived quality. There was also a need to involve second-tier suppliers, as experts on specific sub-components included in the service, to ensure the effective performance of the final service.

Orchestration leads to increased emphasis on value creation in the broader context of the service system, which some observers feel requires a re-evaluation of a firm's whole network of providers, service partners, and customers (Lusch et al., 2010; Agarwal and Selen, 2009). When VehicleCo launched extended maintenance contracts, it had to convince its front-end, customer-facing staff of the benefits of the service. Firms that depend strongly on external dealers have even greater difficulty persuading their own people of the value of service innovation. One case in point is OutdoorCo, which sells through dealers and has neither a local service organization nor a direct relationship with its end customers. Entering the service market to sell such advanced services as performance-based contracts, the firm had to create an incentive system that would benefit both dealers and users.

Several of the case firms asserted the importance of including customers in the 
service system and emphasized the consequent need for orchestration of the process. There would be a need for enhanced interaction, and orchestrating the service system therefore has a close relationship to the interaction microfoundation discussed in subsection 5.2.1.

\subsubsection{Balancing product- and service-innovation related assets}

A constant challenge for the case firms was found to be the need to balance assets related to product-centered and service-centered innovation, to secure the interests of both the product and service functions. As firms increasingly offer advanced services, often combining services and products, they typically find it necessary to add systemic characteristics and integration aspects. Tension between product and service interests was evident in all case firms, as previous studies have noted: for example, Gebauer and Friedl (2005). Given that the product side of the business is a core activity for product-centric firms, a product-oriented core of capabilities and microfoundations (manufacturing, R\&D activities, etc.) will demand ongoing parallel management and development.

Service-related activities and their development often seem to be subservient to product development, creating the need to establish formal service development roles at both operational and strategic levels. GasCo's introduction of service-focused roles (such as service developers) at its operational level, including the appointment of service managers to the firm's board, was found to have contributed to the realization of such benefits as increased service revenues and an increased market penetration.

\subsubsection{Creating a service-oriented mental model}

One of the most difficult and time-consuming elements of reconfiguration is the creation of a service-oriented mental model, which will frame everything the firm 
does. All the case firms acknowledged that this change of mental set was difficult to achieve, but absolutely crucial to long-term success and continuous service innovation (cf., Gebauer and Friedl, 2005). A new menatal model implies not only learning, but also the willingness and ability to unlearn (Sinkula 2002) and reject obsolete routines, which should lead in turn to the adaptation of more effective behaviors (Matthyssens et al., 2006).

The CEO of VehicleCo emphasized the importance of services to his firm. He had started the firm's journey toward a service-oriented mental model by announcing his intention that $50 \%$ of total revenue would in future be attributable to services, including the supply of spare parts. The appointment of a vice president with responsibility for services reinforced that increased commitment to the service orientation. The process of changing the internal norms, values, and business logic at Materials HandlingCo had been constantly ongoing, often characterized by long periods of sustained effort. Across the case firms, service transition had been a timeconsuming, incremental process over several decades. Although many managers had at first seen services as a necessary evil, the firms were today service providers in many senses.

\subsection{Implementation of the microfoundations}

Although the discussed microfoundations were detectable in all participating firms, the degree of implementation differed. Some firms were early identifiers of certain microfoundations as being particularly important for their business, and therefore achieved a higher degree of implementation where those microfoundations are concerned. A number of firms were also facing a faster pace of change, increased competition on their traditional product markets, and changing demands from customers. These pressures forced them to implement more microfoundations and to 
do so to a greater extent. Table 5 shows the level of prevalence of each microfoundation in each case firm, defined as high, medium or low.

Table 5 here

Firms that have a high level of prevalence are actively engaged in exploiting the microfoundation in question, have a structured process in place, commit appropriate resources, and are widely accepting of the microfoundation at several hierarchical levels. Firms characterized as having a medium level of prevalence commit several resources to the microfoundation, have started to discuss processes in a formal setting, and have some top-level support, even if only a limited number of people are directly concerned with these service-related issues. Those found to have a low level of prevalence with respect to a particular microfoundation exhibit a limited interest in it and commit few resources to it (usually only operational), but have at least one service in place in a local key market. For example, the sensing activities of firms with the weakest technological exploration abilities tended to focus on maintaining product leadership by adding new features and incorporating new generations of technologies. Such firms paid minimal attention to future service opportunities. Their overall understanding of the microfoundations was also limited, typically meaning that that very few employees recognized the need for it in practice.

For many firms, including all of those participating in the study reported here, a crucial starting point is endorsement by top-level management. On a more concrete level, firms that have a well-established service delivery organization have been better able to seize service innovation opportunities, and also to transform those opportunities successfully into customer value.

Regarding the general phenomenon of service transition, the firms studied had 
started from very different situations and market environments. The findings of the study therefore cannot confirm a general pattern regarding the sequence of microfoundation development.

\section{Conclusions}

\subsection{Research contribution}

This paper lays claim to three main contributions to the body of knowledge. First, the research extends the existing literature on dynamic capabilities by specifically addressing their application to service industries. Earlier studies exhibit a bias towards products and technological innovation, tending to overlook many service innovations (Michel et al., 2008). Analysis of the service transition phenomenon contributes to the understanding of generic-level dynamic capabilities, specifically of the underlying logic, by identifying the microfoundations that firms must develop in order to achieve service innovation. The study reported here focuses on activities and mechanisms that drive the development of such dynamic capabilities directly.

The list of microfoundations identified is consistent with the work of Eisenhardt and Martin (2000) in laying no claim to being either a comprehensive or exhaustive inventory of all possibilities. Rather, they have a solid grounding in the reality that many firms face. Dynamic capabilities may be evaluated conceptually from two perspectives: evolutionary and technical fitness (Teece, 2007). Evolutionary fitness describes the ability of dynamic capabilities to enable firms to align with environmental change, create value, and prosper in the marketplace. Technical fitness refers to the capacity of a dynamic capability to carry out its designated task (Helfat et al., 2007). In adding microfoundations that enable service innovation to the existing dynamic capabilities framework, the present study focuses primarily on a firm's ability to increase evolutionary fitness. That enhancement can in turn be expected to 
improve service performance. Furthermore, a greater emphasis on the microfoundations should also increase the technical fitness of dynamic capabilities as the firm becomes more skilled in their use over time. The challenge for many firms, however, is to identify and subsequently implement the microfoundations appropriate to external changes and demands.

The second theoretical contribution of the study is that it extends existing work on the relatively young research field of service innovation into the manufacturing industries. It does so by identifying the key microfoundations on which such firms need to focus if they are to increase the service content of their business portfolio. Since service firms are the primary empirical base of previous research into service innovation, the focus on an industrial setting helps fill that research gap. The research findings show that relying on product-driven and manufacturing-driven microfoundations (and consequent capabilities) is not sufficient for success in service innovation; a new set of microfoundations is required.

The third contribution of the research is that it provides empirical evidence of dynamic capabilities in practice, especially in industrial settings where the service perspective may be novel. Previous research into dynamic capabilities has been mainly conceptual and focused on more product related issues. The point of departure for the study reported here is the proposition that, to compete effectively in the marketplace, product-centric firms need to focus on the concomitant service as well as the product and place greater emphasis on service innovation. A major challenge posed by this shift in the business model is to manage and extend the dynamic capabilities of sensing, seizing, and reconfiguring (Teece, 2007), which are essential to successful service innovation. The study has identified microfoundations that form the basis of successful realignment of a firm's dynamic capabilities, in such a way as 
to achieve a better fit with service innovation initiatives. Thus, because service innovation requires changes throughout the organization, firms must adopt a multidimensional perspective on service innovation (Bessant and Davies, 2007; Tidd et al., 2001).

Although the discussed microfoundations are identifiable in all firms, the extent to which they are implemented and activated varies (see Table 5). They should therefore be regarded more as propositions than as necessary preconditions. The findings show that there is no single best way to become service oriented, and also hint at the pathdependent characteristics of dynamic capabilities. Thus, firms may in practice differ in terms of the sequence in which they develop microfoundations.

\subsection{Managerial implications}

The microfoundations identified and discussed in this research study are cornerstones of a strategy for firms aiming to introduce service innovation into their organizations. These microfoundations offer managers insights into the aspects on which to focus in their efforts to enhance service innovation initiatives. Because they and the subsequent dynamic capabilities are typically path-dependent and related to the idiosyncrasies of the particular firm, managers must understand their firm's specific situation, the environment in which it is operating, and the pace of change, so as to choose and develop situation-specific microfoundations. The sequence in which those are developed may furthermore vary according to the firm's idiosyncrasies and to external stimuli.

Organizational challenges are present in all three classes of dynamic capability. Two levels of the sensing capability are discernable: one at the front line, where there is interaction with customers, and the other at a higher level in the organization, where data are centrally aggregated and analyzed. In service innovation, these mechanisms 
assume a special emphasis. Given that the discovery of opportunities often takes place during interactions with customers, front-line personnel must have the appropriate skills and tools for opportunity-sensing. The availability of those resources will depend on the existence of relevant organizational processes, just as central resources need to be available for the monitoring of macro-level technological developments and market changes.

Challenges to the seizing capability relate to organizational arrangements and the strategy-environment fit. A wider perspective on service systems and value creation brings with it the need for continuous updating of areas of responsibility and interfaces between different functions. Important tasks for management include external coordination and prioritization of relationships, as well as their re-evaluation and revision over time.

One of the most challenging microfoundations associated with the reconfiguring capability is to implement a shift toward a service-oriented mental model within the organization. In that regard, senior management must play the crucial role of messenger and ambassador, proposing and leading change while championing service-oriented attitudes. Creating the right culture involves a long list of tangible management tasks, including organizational change, outsourcing, the management of relationships within the service system, and striking the right balance between service and product.

\subsection{Further research and limitations}

Though the study reported here was an exploratory attempt to identify key microfoundations, questions arise regarding the methods by which they are generated and implemented. As a logical extension of the current research, investigation of the 
actual process of generation and the sequence of development should yield results with interesting implications for both research and practice. Further research might also usefully evaluate the performance of the identified microfoundations and assess the effect on overall corporate performance. Such an analysis would imply a greater focus on the technical fitness of the dynamic capabilities.

A second limitation of the study relates to the measurement of a firm's performance. The operating assumption that the microfoundations are necessary and do indeed contribute to stronger corporate performance is matched by a strong conviction among the participating firms, but the study did not explicitly measure that outcome. As Helfat et al. (2007) observe, linking microfoundations to performance is complicated, given that financial measures tend to underestimate value creation in general and that attributable to services in particular. Furthermore, though the research method was in-depth multiple case studies, access to primary data from customers, service partners, and dealers was limited. Richer data would have provided valuable additional insights capable of either confirming or modifying the findings. Lastly, the product-centric characteristics of the firms studied limits the scope for tends to complicate generalization to other contexts. Such future topics of study as the dynamic capabilities and microfoundations of pure service firms could enhance understanding of service innovation and shed new light on the context-specific issues uncovered by the present research. 


\section{REFERENCES}

Agarwal, R., \& Selen, W. (2009). Dynamic Capability Building in Service Value Networks for Achieving Service Innovation. Decision Sciences, 40(3), 431475.

Anderson, J. C., Kumar, N., \& Narus, J. A. (2007). Value Merchants: Demonstrating and Documenting Superior Value in Business Markets. Boston, MA: Harvard Business School Press.

Alam, I. (2006). Removing the fuzziness from the fuzzy front-end of service innovations through customer interactions. Industrial Marketing Management, 35(4), 468-480.

Atuahene-Gima, K. (1996). Market orientation and innovation. Journal of Business Research, 35(2), 93-103.

Bessant, J., \& Davies, A. (2007). Managing service innovation, in Innovation in Services (DTI Occasional Paper No. 9), London, UK: Department of Trade and Industry.

Chesbrough, H. (2010). Business Model Innovation: Opportunities and Barriers. Long Range Planning, 43(2-3), 354-363.

Davies, A., Brady, T., \& Hobday, M. (2006). Charting a Path toward Integrated Solutions. Sloan Management Review, 47(3), 39-48.

Davies, A. (2004). Moving base into high-value integrated solutions: a value stream approach. Industrial and Corporate Change, 13(5), 727-756.

Day, G. S. (2004). The capabilities of market-driven organizations. Journal of Marketing, 58(4), 37-52.

Den Hertog, P., van der Aa, W., \& de Jong, M. W. (2010). Capabilities for managing 
service innovation: towards a conceptual framework. Journal of Service Management, 21(4), 490-514.

De Jong, J. P., \& Vermeulen, P. A. (2003). Organizing successful new service development: a literature review. Management Decision, 41(9), 844-858.

De Vries, E. J. (2006). Innovation in services in networks of organizations and in the distribution of services. Research Policy, 35, 1037-1051.

Drejer, I. (2004). Identifying innovation in surveys of services: a Schumpeterian perspective. Research Policy, 33(3), 551-562.

Dubois, A., Gadde, L. E. (2002). Systematic combining: An abductive approach to case research. Journal of Business Research, 55(7), 553-560.

Edvardsson, B., Gustafsson, A., Kristensson, P., Magnusson, P., \& Matthing, J. (2006). Involving Customers in New Service Development. London: Imperial College Press.

Edvardsson, B., \& Olsson, J. (1997). Key concepts for new service development. The Service Industries Journal, 16(2), 140-164.

Eisenhardt, K. M. (1989). Building Theories from Case Study Research. Academy of Management Review, 14(4), 532-550.

Eisenhardt, K. M., Graebner, M. E. (2007). Theory building from cases: Opportunities and challenges. Academy of Management Journal, 50(1), 25-32.

Eisenhardt, K. M., Martin, J. A. (2000). Dynamic capabilities: What are they? Strategic Management Journal, 21(10/11), 1105-1121.

Fischer, T., Gebauer, H., Gregory, M., Ren, G., \& Fleisch, E. (2010). Exploitation or exploration in service business development? Insights from a dynamic capabilities perspective. Journal of Service Management, 21(5), 591-624. 
Gallouj, F., \& Weinstein, O. (1997). Innovation in services. Research Policy, 26(4/5), 537-556.

Gallouj, F. (2002). Innovation in the service economy: the new wealth of nations. Cheltenham, UK: Edward Elgar.

Gebauer, H., \& Friedli, T. (2005). Behavioral implications of the transition process from products to services. Journal of Business \& Industrial Marketing, 20(2), 70-78.

Gebauer, H., Gustafsson, A., \& Witell, L. (2011) Competitive advantage through service differentiation by manufacturing companies. Journal of Business Research, 64(12), 1270-1280.

Gibbert, M., Ruigrok, W., \& Wicki, B. (2008). What passes as a rigorous case study? Strategic Management Journal, 29(13), 1465-1474.

Grönroos, C., \& Ojasalo, K. (2004). Service productivity: Towards a conceptualization of the transformation of inputs into economic results in services. Journal of Business Research, 57, 414-423.

Grönroos, C. (2007). Service Management and Marketing - Customer Management in Service Competition. (3rd ed.) Chichester, UK: John Wiley \& Sons.

Helfat, C., Finkelstein, S., Mitchell, W., Peteraf, M. A., Singh, H., Teece, D. T., \& Winter, S. (2007). Dynamic capabilities: Understanding strategic change in organizations. MA: Blackwell.

Jacob, F., \& Ulaga, W. (2008). The transition from product to service in business markets: An agenda for academic inquiry. Industrial Marketing Management, 37(3), 247-253.

Jong, J. P. J., \& Vermeulen, P. A. M. (2003). Organizing successful new service development: a literature review. Management Decision, 41(9), 844-858. 
Kindström, D., \& Kowalkowski, C. (2009). Development of industrial service offerings - A process framework. Journal of Service Management, 20(2), 156172.

Kindström, D. (2010). Towards a service-based business model - Key aspects for future competitive advantage. European Management Journal, 28(6), 479490.

Kohli, A. K., \& Jaworski, B. J. (1990). Market orientation: the construct, research propositions, and managerial implications. Journal of Marketing, 54(2), 1-18.

Kowalkowski, C. (2011). Dynamics of value propositions: insights from servicedominant logic. European Journal of Marketing, 45(1/2), 277-294.

Kowalkowski, C., Kindström, D., Brashear, T. A., Brege, S., \& Biggeman, S. (2012). Service infusion as agile incrementalism in action. Journal of Business Research, 65, Article in press, doi:10.1016/j.jbusres.2010.12.014.

Kowalkowski, C., Kindström, D., \& Witell, L. (2011). Internalization or externalization? Examining organizational arrangements for industrial services. Managing Service Quality, 21(4), 373-391.

Lay, G., Schroeter, M., \& Biege, S. (2009). Service-based business concepts: A typology for business-to-business markets. European Management Journal, 27(6), 442-455.

Leonard-Barton, D. (1992). Core Capabilities and Core Rigidities: A Paradox in Managing New Product Development. Strategic Management Journal, 13(Summer), 111-125.

Lisboa, A., Skarmeas, D., Lages, C. (2011). Innovative capabilities: Their drivers and effects on current and future performance. Journal of Business Research, 64(11), 1157-1161. 
Lovelock, C. H. (1984). Developing and Implementing new services. In W.R. George \& C. E. Marshall (Eds.), Developing New Services (p. 44-64). Chicago: American Marketing Association.

Lusch, R. F., Vargo, S. L., \& Tanniru, M. (2010). Service, value networks and learning. Journal of the Academy of Marketing Science, 38(1), 19-31.

Mannervik, U., \& Ramírez, R. (2006). Customers as Co-Innovators: An Initial Exploration of Its Strategic Importance. In, B. Edvardsson, A. Gustafsson, P. Kristensson, P. Magnusson, \& J. Matthing (Eds). Involving Customers in New Service Development. London: Imperial College Press.

Martin, C. R., \& Horne, D. A. (1992). Restructuring towards a Service Orientation: The Strategic Challenges. International Journal of Service Industry Management, 3(1), 25-38.

Mathieu, V. (2001). Product services: from a service supporting the product to a service supporting the client. Journal of Business \& Industrial Marketing, 16(1), 39-61.

Matthyssens, P., \& Vandenbempt, K. (1998). Creating competitive advantage in industrial services. Journal of Business \& Industrial Marketing, 13(4/5), 339355.

Matthyssens, P., Vandenbempt, K., \& Berghman, L. (2006). Value innovation in business markets: Breaking the industry recipe. Industrial Marketing Management, 35(6), 751-761.

Michel, S., Brown, S. W., and Gallan, A. S. (2008). An expanded and strategic view of discontinuous innovations: deploying a service-dominant logic. Journal of the Academy of Marketing Science, 36(1), 54-66.

Neu, W., \& Brown, S. (2008). Manufacturers forming successful complex business 
services: Designing an organization to fit the market. International Journal of Service Industry Management, 19(2), 232-251.

Ng, I., Maull, R., \& Yip, N. (2009). Outcome-based contracts as a driver for systems thinking and service-dominant logic in service science: Evidence from the defense industry. European Management Journal, 27(6), 377-387.

Normann, R. (2001). Reframing Business - When the Map Changes the Landscape. ( $1^{\text {st }}$ ed.) Chichester, UK: Wiley.

Ostrom, A. L., Bitner, M. J., Brown, S. W., Burkhard, K. A., Goul, M., SmithDaniels, V., Demirkan, H., \& Rabinovich, E. (2010). Moving Forward and Making a Difference: Research Priorities for the Science of Service. Journal of Service Research, 13(1), 4-36.

Prasnikar, J., Lisjak, M., Buhovac, A. R., \& Stembergar, M. (2008). Identifying and Exploiting the Inter-relationships between Technological and Marketing Capabilities. Long Range Planning, 41, 530-554.

Raddats, C., \& Easingwood, C. (2010). Services growth options for B2B productcentric businesses. Industrial Marketing Management, 39(8), 1334-1345.

Shah, D., Rust, R., Parasuraman, A., Staelin, R., \& Day, G. S. (2006). The Path to Customer Centricity. Journal of Service Research, 9(2), 113-124.

Siggelkow, N., Rivkin, J. W. (2005). Speed and Search: Designing Organizations for Turbulence and Complexity. Organization Science, 16(2), 101-122.

Sinkula, J. M. (2002). Market-based success, organizational routines, and unlearning. Journal of Business \& Industrial Marketing, 17(4), 253-269.

Song, L. Z., Song, M., \& Di Benedetto, C. A. (2009). A Staged Service Innovation Model. Decision Sciences, 40(3), 571-599. 
Stevens, E. \& Dimitriadis, S. (2004). New service development through the lens of organisational learning: evidence from longitudinal case studies. Journal of Business Research, 57(10), 1074-1084.

Stewart, D. W. \& Shamdasani, P.N. (1990). Focus Groups: Theory and Practice. Thousand Oaks, CA: Sage Publications.

Sundbo, J. (1997). Management of Innovation in Services. Service Industries Journal, 17(3), 432-455.

Tallman, S. (2003). Dynamic capabilities. In D. O. Faulkner, \& A. Campbell (Eds.), Handbook of Strategy: A Strategy Overview and Competitive Advantage. Oxford, UK: Oxford University Press.

Teece, D. J., Pisano, G., \& Shuen, A. (1997). Dynamic capabilities and strategic management. Strategic Management Journal, 18(7), 509-533.

Teece, D. J. (2007). Explicating dynamic capabilities: The nature and microfoundations of sustainable enterprise performance. Strategic Management Journal, 28(13), 1319-1350.

Teece, D. J. (2010). Business Models, Business Strategy and Innovation. Long Range Planning, 43(2/3), 172-194.

Tidd, J., Bessant, J., \& Pavitt, K. (2005). Managing innovation: Integrating technological, market and organizational change. Chichester, UK: Wiley.

Ulaga, W., \& Eggert, A. (2006). Value-Based Differentiation in Business Relationships: Gaining and Sustaining Key Supplier Status. Journal of Marketing, 70(1), 119-136.

Utterback, J. M. (1994). Mastering the dynamics of innovation. Boston, MA: Harvard Business School Press. 
Van de Ven, A. H., \& Johnson, P. E. (2006). Knowledge for theory and practice. Academy of Management Review, 31(4), 802-821.

Vargo, S. L., \& Lusch, R. F. (2008). Service-dominant logic: continuing the evolution. Journal of the Academy of Marketing Science, 36(1), 1-10.

Winter, S. G. (2003). Understanding dynamic capabilities. Strategic Management Journal, 24(10), 991-995.

Yin, R. K. (2003). Case Study Research: Design and Methods. Thousand Oaks, CA: Sage Publications.

Zollo, M., \& Winter, A. (2002). Deliberate Learning and the Evolution of Dynamic Capabilities. Organization Science, 13(3), 339-351. 
Table 1. Case firms and typical examples of their service.

\begin{tabular}{|c|c|c|c|c|}
\hline Firm & Size & Core business & Typical services & $\begin{array}{l}\text { Recent key service } \\
\text { innovation }\end{array}$ \\
\hline AircraftCo & $\begin{array}{l}\text { Approx } 12,000 \text { employees } \\
\text { Turnover approx } € 2.5 \text { billion }\end{array}$ & $\begin{array}{l}\text { Aircrafts and related } \\
\text { parts }\end{array}$ & $\begin{array}{l}\text { Maintenance } \\
\text { contracts }\end{array}$ & $\begin{array}{l}\text { Availability contract } \\
\text { for products }\end{array}$ \\
\hline GasCo & $\begin{array}{l}\text { Approx } 1,000 \text { employees } \\
\text { Turnover approx } € 0.3 \text { billion }\end{array}$ & $\begin{array}{l}\text { Industrial gases and } \\
\text { associated equipment }\end{array}$ & $\begin{array}{l}\text { Continuous supply } \\
\text { of product }\end{array}$ & Service concept \\
\hline $\begin{array}{l}\text { Materials } \\
\text { HandlingCo }\end{array}$ & $\begin{array}{l}\text { Approx 8,900 employees } \\
\text { Turnover approx } € 1.6 \text { billion }\end{array}$ & $\begin{array}{l}\text { Materials handling } \\
\text { equipment }\end{array}$ & $\begin{array}{l}\text { Rental plans and } \\
\text { maintenance } \\
\text { contracts }\end{array}$ & $\begin{array}{l}\text { Fleet management } \\
\text { solution }\end{array}$ \\
\hline MiningCo & $\begin{array}{l}\text { Approx 8,500 employees } \\
\text { Turnover approx } € 2 \text { billion }\end{array}$ & Mining equipment & Process consulting & $\begin{array}{l}\text { Revenue scheme for } \\
\text { advanced services }\end{array}$ \\
\hline OutdoorCo & $\begin{array}{l}\text { Approx 15,000 employees } \\
\text { Turnover approx } € 3 \text { billion }\end{array}$ & $\begin{array}{l}\text { Outdoor power products } \\
\text { for professional use }\end{array}$ & $\begin{array}{l}\text { Support and service } \\
\text { contracts }\end{array}$ & $\begin{array}{l}\text { Service contracts } \\
\text { provided by dealers }\end{array}$ \\
\hline $\begin{array}{l}\text { Industrial } \\
\text { PumpsCo }\end{array}$ & $\begin{array}{l}\text { Approx 4,500 employees } \\
\text { Turnover approx } € 1 \text { billion }\end{array}$ & Industrial pumps & $\begin{array}{l}\text { Monitoring and } \\
\text { control services }\end{array}$ & Process analysis \\
\hline VehicleCo & $\begin{array}{l}\text { Approx 8,000 employees } \\
\text { Turnover approx } € 2 \text { billion }\end{array}$ & Heavy vehicles & $\begin{array}{l}\text { Maintenance } \\
\text { contracts }\end{array}$ & $\begin{array}{l}\text { Service level } \\
\text { agreement }\end{array}$ \\
\hline WeldingCo & $\begin{array}{l}\text { Approx 8,000 employees } \\
\text { Turnover approx } € 1 \text { billion }\end{array}$ & Welding equipment & $\begin{array}{l}\text { Retrofits and } \\
\text { upgrades }\end{array}$ & Upgrade of services \\
\hline
\end{tabular}

Note:

$€ 1.00=$ US\$1.29 at January 2012 (Reuters) 
Table 2. Sensing: microfoundations and key questions

\begin{tabular}{lll}
\hline $\begin{array}{l}\text { Dynamic } \\
\text { capability }\end{array}$ & $\begin{array}{l}\text { New service-innovation-oriented } \\
\text { microfoundations }\end{array}$ & Critical managerial questions \\
\hline Sensing & $\begin{array}{l}\text { Customer-linked service sensing: Building up } \\
\text { deep customer knowledge, including } \\
\text { institutionalizing feedback loops and creating } \\
\text { organizational roles, systems, and processes that } \\
\text { continuously capture and relay customer } \\
\text { demands. }\end{array}$ & $\begin{array}{l}\text { Who interacts with the } \\
\text { customer and how do we } \\
\text { systematically capture and } \\
\text { relay that information? }\end{array}$ \\
& $\begin{array}{l}\text { Service system sensing: Building up an } \\
\text { understanding of the entire service system, } \\
\text { including links to partners and suppliers, and } \\
\text { creating network skills. }\end{array}$ & $\begin{array}{l}\text { Who interacts with service } \\
\text { partners and suppliers, and } \\
\text { what lateral roles and processes } \\
\text { do we have in place to capture } \\
\text { this? }\end{array}$ \\
& $\begin{array}{l}\text { Do we have service-dedicated } \\
\text { roles and teams? }\end{array}$ \\
& $\begin{array}{l}\text { What interfaces do we have } \\
\text { Internal service sensing: Building up internal } \\
\text { sensing: e.g. opportunities related to the } \\
\text { integration of products and services and the } \\
\text { detection of decentralized initiatives. Having a } \\
\text { structured service development process to } \\
\text { address this factor. }\end{array}$ & $\begin{array}{l}\text { between central and local } \\
\text { service units and between } \\
\text { functions? }\end{array}$ \\
$\begin{array}{ll}\text { Technology exploration: Scanning and exploring } \\
\text { sources outside the service system, primarily } \\
\text { related to more radical technological changes. }\end{array}$ & $\begin{array}{l}\text { What new-to-industry } \\
\text { technologies are emerging, } \\
\text { from which we could derive } \\
\text { service value in our specific } \\
\text { context? }\end{array}$ \\
\hline
\end{tabular}


Table 3. Seizing: microfoundations and key questions

\begin{tabular}{|c|c|c|}
\hline $\begin{array}{l}\text { Dynamic } \\
\text { capability }\end{array}$ & $\begin{array}{l}\text { New service-innovation-oriented } \\
\text { microfoundations }\end{array}$ & Critical managerial questions \\
\hline \multirow[t]{4}{*}{ Seizing } & $\begin{array}{l}\text { Service interactions: Interacting and co-developing } \\
\text { with customers and partners to understand, visualize, } \\
\text { and deliver value propositions. Involves processes, } \\
\text { roles, and skills to interact and change together with } \\
\text { customers. }\end{array}$ & $\begin{array}{l}\text { What are we good at and what } \\
\text { can we benefit from letting } \\
\text { others do? Who owns the } \\
\text { customer interface? }\end{array}$ \\
\hline & $\begin{array}{l}\text { Managing the service delivery process: Having the } \\
\text { ability to restructure internal and external resources } \\
\text { swiftly, for the delivery of new or improved services, } \\
\text { including roles dedicated to services at both } \\
\text { operational and strategic levels. }\end{array}$ & $\begin{array}{l}\text { Who assumes the risk, and the } \\
\text { ultimate responsibility? Do we or } \\
\text { should we own our own service } \\
\text { function? What type of services } \\
\text { should we perform in-house? }\end{array}$ \\
\hline & $\begin{array}{l}\text { Structuring the service development process: } \\
\text { Structuring a service development process and being } \\
\text { flexible as the process develops. }\end{array}$ & $\begin{array}{l}\text { How should we develop } \\
\text { services (e.g., milestones, } \\
\text { gates, structure)? What are the } \\
\text { linkages to the product } \\
\text { development process? } \\
\text { What value are customers }\end{array}$ \\
\hline & $\begin{array}{l}\text { Adopting new revenue mechanisms: Rolling out new } \\
\text { revenue mechanisms based on service value, such as } \\
\text { availability and customer productivity. The ability to } \\
\text { visualize the value of new, often intangible services } \\
\text { and solutions for a wide array of actors in the service- } \\
\text { delivery system. }\end{array}$ & $\begin{array}{l}\text { interested in? How can we } \\
\text { communicate our value? What } \\
\text { changes in the revenue streams } \\
\text { can we introduce? }\end{array}$ \\
\hline
\end{tabular}


Table 4. Reconfiguring: microfoundations and key questions

\begin{tabular}{lll}
\hline $\begin{array}{l}\text { Dynamic } \\
\text { capability }\end{array}$ & $\begin{array}{l}\text { New service-innovation-oriented } \\
\text { microfoundations }\end{array}$ & Critical managerial questions \\
\hline Reconfiguring & $\begin{array}{l}\text { Orchestrating the service system: Managing and } \\
\text { transforming the service system, especially } \\
\text { managing external actors central to performance } \\
\text { of the service. An ability to extend the resource } \\
\text { base into new markets and services, and to } \\
\text { incorporate complementary resources and co- } \\
\text { specialization. Reconfiguring roles, resources, } \\
\text { locus of control, and power in the service system. }\end{array}$ & $\begin{array}{l}\text { What partners should we have? } \\
\text { How much risk are we willing } \\
\text { to take on? What roles and } \\
\text { structures can we implement? } \\
\text { Should we, for example, create } \\
\text { new roles and teams focused } \\
\text { purely on services? }\end{array}$ \\
$\begin{array}{l}\text { Balancing product and service-innovation related } \\
\text { assets: Maintaining a balanced relationship } \\
\text { between the service organization and the product } \\
\text { organization, necessitating the creation of roles } \\
\text { designed for service on all levels of the } \\
\text { organizational structure. }\end{array}$ & $\begin{array}{l}\text { How do we simultaneously } \\
\text { encourage product and service } \\
\text { development? What new } \\
\text { reward systems can we } \\
\text { introduce? }\end{array}$ \\
$\begin{array}{ll}\text { Creating service-oriented mental model: Often } \\
\text { referred to as a service logic; implies a learning } \\
\text { dimension. }\end{array}$ & $\begin{array}{l}\text { How do we change the mental } \\
\text { model of a primarily } \\
\text { production-oriented } \\
\text { organization? }\end{array}$ \\
&
\end{tabular}


Table 5. Summary of identified microfoundations and their.

\begin{tabular}{|c|c|c|c|c|c|c|c|c|}
\hline $\begin{array}{l}\text { Micro- } \\
\text { foundation }\end{array}$ & AircraftCo & GasCo & $\begin{array}{c}\text { Materials } \\
\text { HandlingCo }\end{array}$ & MiningCo & OutdoorCo & $\begin{array}{l}\text { Industrial } \\
\text { PumpsCo }\end{array}$ & VehicleCo & WeldingCo \\
\hline $\begin{array}{l}\text { Customer- } \\
\text { linked } \\
\text { service } \\
\text { sensing }\end{array}$ & $\bar{M}$ & $\mathrm{H}$ & $\mathrm{M}$ & $\bar{M}$ & $\mathrm{~L}$ & $\mathrm{~L}$ & $\mathrm{~L}$ & $\mathrm{~L}$ \\
\hline $\begin{array}{l}\text { Service } \\
\text { system } \\
\text { linking }\end{array}$ & $\mathrm{L}$ & $\mathrm{L}$ & M & M & M & M & M & $\mathrm{L}$ \\
\hline $\begin{array}{l}\text { Internal } \\
\text { sensing }\end{array}$ & $\mathrm{L}$ & M & $\mathrm{H}$ & $\mathrm{L}$ & $\mathrm{L}$ & M & M & M \\
\hline $\begin{array}{l}\text { Technology } \\
\text { exploration }\end{array}$ & M & M & $\mathrm{H}$ & M & M & M & $\mathrm{H}$ & $\mathrm{L}$ \\
\hline $\begin{array}{l}\text { Service } \\
\text { interaction }\end{array}$ & $\mathrm{H}$ & $\mathrm{H}$ & $\mathrm{H}$ & $\mathrm{M}$ & $\mathrm{L}$ & $\mathrm{M}$ & $\mathrm{M}$ & $\mathrm{M}$ \\
\hline $\begin{array}{l}\text { Service } \\
\text { delivery }\end{array}$ & $\mathrm{L}$ & $\mathrm{H}$ & $\mathrm{H}$ & $\mathrm{H}$ & $\mathrm{L}$ & M & M & $\mathrm{L}$ \\
\hline $\begin{array}{l}\text { Service } \\
\text { development }\end{array}$ & $\mathrm{L}$ & $\mathrm{H}$ & M & M & $\mathrm{L}$ & $\mathrm{L}$ & M & $\mathrm{L}$ \\
\hline $\begin{array}{l}\text { Revenue } \\
\text { mechanisms }\end{array}$ & M & M & $\mathrm{H}$ & M & $\mathrm{L}$ & $\mathrm{L}$ & $\mathrm{H}$ & $\mathrm{L}$ \\
\hline Orchestrating & $\mathrm{M}$ & $\mathrm{M}$ & $\mathrm{M}$ & $\mathrm{M}$ & $\bar{L}$ & $\mathrm{M}$ & $\mathrm{M}$ & $\bar{L}$ \\
\hline Balancing & $\mathrm{L}$ & M & $\mathrm{H}$ & $\mathrm{L}$ & $\mathrm{L}$ & $\mathrm{L}$ & M & $\mathrm{L}$ \\
\hline $\begin{array}{l}\text { Mental } \\
\text { model }\end{array}$ & $\mathrm{L}$ & M & M & $\mathrm{L}$ & $\mathrm{L}$ & $\mathrm{L}$ & M & $\mathrm{L}$ \\
\hline
\end{tabular}

$\mathrm{H}=$ high; $\mathrm{M}=$ medium; $\mathrm{L}=$ low 